http://doi.org/10.35784/iapgos.2193

\title{
SELECTED ASPECTS IN THE ANALYSIS OF THE COMBUSTION PROCESS USING WAVELET TRANSFORM
}

\author{
Żaklin Grądz \\ Lublin University of Technology, Department of Electronics and Information Technology, Lublin, Poland
}

Abstract. The complexity of changes occurring in the flame during the combustion process has a direct influence on the quantity and quality of the combustion products. The presented measurement data pertaining to the changes in flame luminosity were recorded using a specialized monitoring system. These signals from the combustion of such fuels as pulverized coal and mazout were recorded with high sampling rate. The paper presented the analysis of changes in flame luminosity for different fuels using continuous and discrete wavelet transform. The main aim of the studies was to determine the scale values, which enable differentiating between the type of combusted fuel. The results of studies were presented in the form of scalograms.

Keywords: scalogram, continuous and discrete wavelet transform, diagnostics

\section{WYBRANE ASPEKTY W ANALIZIE PROCESU SPALANIA Z WYKORZYSTANIEM PRZEKSZTALCEŃ FALKOWYCH}

Streszczenie. Złożoność zmian zachodzących $w$ płomieniu $w$ trakcie procesu spalania różnych paliw ma bezpośredni wplyw na ilość $i$ jakość powstałych produktów spalania. Przedstawione $w$ pracy dane pomiarowe zmian intensywności świecenia płomienia zostaty zarejestrowane przy użyciu specjalistycznego systemu monitorującego. Sygnały te, dla procesu spalania, zostały zarejestrowane z wysoka częstotliwościa próbkowania. W artykule przedstawiono analize zmian intensywności świecenia płomienia dla różnych paliw przy zastosowaniu ciagłego i dyskretnego przekształcenia falkowego. Podstawowym celem badań byto określenie wartości skali, na podstawie których możliwe będzie rozróżnienie rodzaju spalanego paliwa. Wyniki badań zostały zaprezentowane w postaci skalogramów.

Słowa kluczowe: skalogram, ciągłe i dyskretne przekształcenie Falkowe, diagnostyka

\section{Introduction}

Environmental pollution is a global problem. The use of fossil fuels in the energy industry, especially coal, leads to the emission of pollutants into the atmosphere. There are many technologies and different legal solutions which aim mainly at protecting the natural environment. The diagnostics and monitoring methods, used in the process of combustion, are helpful for this purpose $[10,14]$. These issues were broadly discussed in the studies $[5,8,11-13]$.

Signals from the combustion process show how the parameters of this phenomenon change over time. The wavelet transform, which enables time-frequency interpretation of signals, is perfectly suited for the analysis of this type of data. This method allows to locate significant frequency changes in the analysis of changes taking place in the flame. The use of the wavelet transform in the signal analysis has been presented in the papers $[3-4,17]$

The article presents the measurement data of the flame acquired during the combustion of pulverized coal and cocombustion of coal with mazout with the use of fiber-optic sampling. The analysis of signals was conducted with the use of continuous and discrete wavelet transform $[2,7,15]$. Due to the fact that the measurement data from the flame are recorded in discrete time intervals and are of a continuous nature, they can be used in both types of transforms. When comparing both transforms, one should note that continuous wavelet transform can be calculated for every scale value.

The results of these analyses are presented in the form of the scalograms. They are defined as energy density $P w f$ of the function $f$, which is defined with the use of analytical wavelet transform. In the continuous wavelet analysis, the signal is defined with the transform parameters, such as scale (a) and shift (b). However, in the case of the discrete wavelet transform, which is the basis of multiresolution analysis (MRA), the signal is divided into approximations and details $[2,7,15]$.

\section{Continuous and discrete wavelet transform}

The application of wavelet transform in the analysis of signals enables its interpretation in the time-frequency domain. In this method, the signal transformation in the time domain includes all

instants in its range. The analyzed signal is presented in the timescale relationship for different resolutions, in this case the scale is equivalent to frequency in Fourier transform $[2,15]$.

The continuous wavelet transform of the signal $f(t) \in L^{2}$ is presented in the following form [2]:

$$
W f(b, a)=\int_{-\infty}^{\infty} f(t) \psi_{a b}(t) d t
$$

where:

$W f(b, a)$ is the wavelet coefficient,

$\psi_{\mathrm{ab}}$ is the basic wavelet,

$\mathrm{a}$ - the parameter determining the scale,

$\mathrm{b}-$ the parameter determining the shift.

The scale can be changed by: stretching (increasing) and compression (decreasing). The wavelet coefficient for a narrow wavelet characterized by a small scale are high-frequency components, while for a large-scale wavelet (broad wavelet) - low frequency components [2].

The discrete wavelet transform, which constitutes a basis for the multiresolution analysis of the signal $f(t) \in L^{2}$, assumes the following form [2]:

$$
f(t)=\sum_{m, n} d_{m}[n] \psi_{m n}
$$

where:

$d_{m}[n]=\left(f, \psi_{m n}\right)$ are wavelet coefficients,

$f(t)$ - signal,

$\psi_{m n}$ - basic wavelet,

$n$ - parameter determining the moment in which the signal is analyzed,

$\mathrm{m}$ - parameter determining the scale and frequency range.

The analysis of signals using the multiresolution analysis method results in the decomposition of a signal into numerous approximation components (low-frequency) and detail components (high-frequency). In continuous wavelet transform, the transform coefficients for a wide wavelet at a given scale correspond to the approximation components of the highest discrete wavelet transform level [2, 7, 15]. Using the narrow wavelet, it is possible to separate dynamic features, corresponding to detail components in discrete wavelet transform. The applications of continuous and discrete wavelet transforms are presented in $[1,9,16]$. 


\section{Results of studies on changes in flame luminosity}

The diagnostic system used for the acquisition of measurement data from the combustion process is based on optical technology. This method enables to perform measurements in the way that does not interfere with the combustion process. Direct recording of the measurement data from flame in the combustion chamber is performed using a fiber-optic measurement probe, which transmits data to the optoelectronic block.

The paper presented the research on changes in flame luminosity, which was conducted for the pulverized coal and a mixture of coal and mazout. Measurement data for the fuel - coal dust with an admixture of mazout was recorded during the firing up of the station.

Mazout is the heavy fraction of crude oil distillation carried out at atmospheric pressure [6]. During the combustion process, mazout is used for kindling or in exceptional situations, e.g. when the flame goes out unexpectedly.

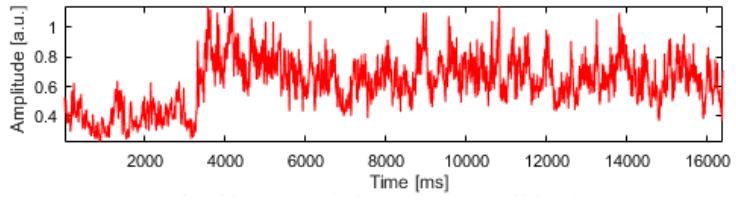

Fig. 1. Characterization of changes in flame luminosity for mazout
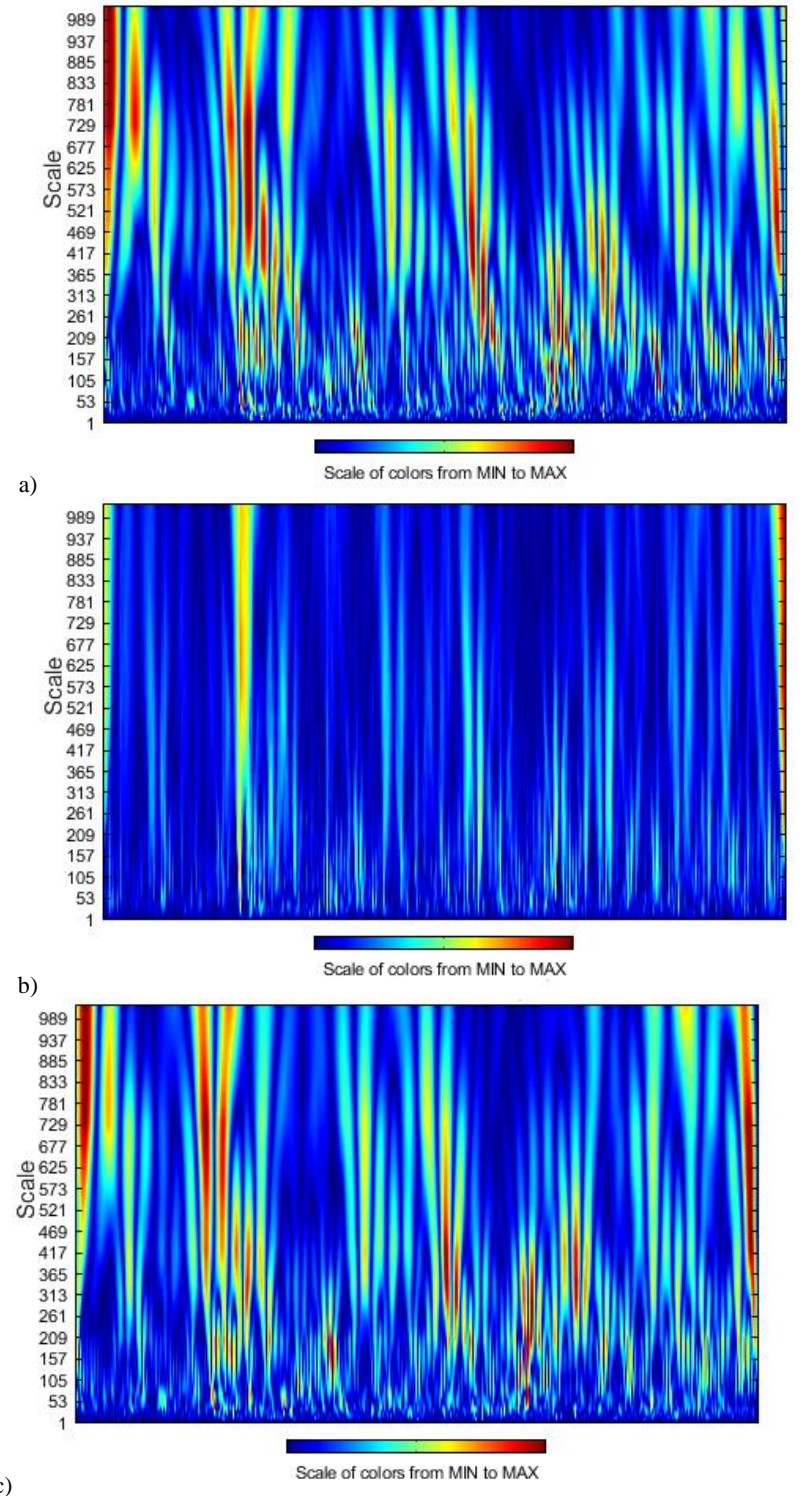

Fig. 2. Scalogram showing the result of analysis using a) Daubechies4 wavelet, b) Haar wavelet, c) Symlet6 wavelet in continuous wavelet transform for pulverized coal and mazout

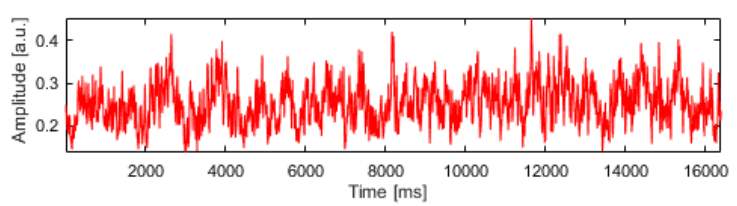

Fig. 3. Characterization of changes in flame luminosity for pure coal
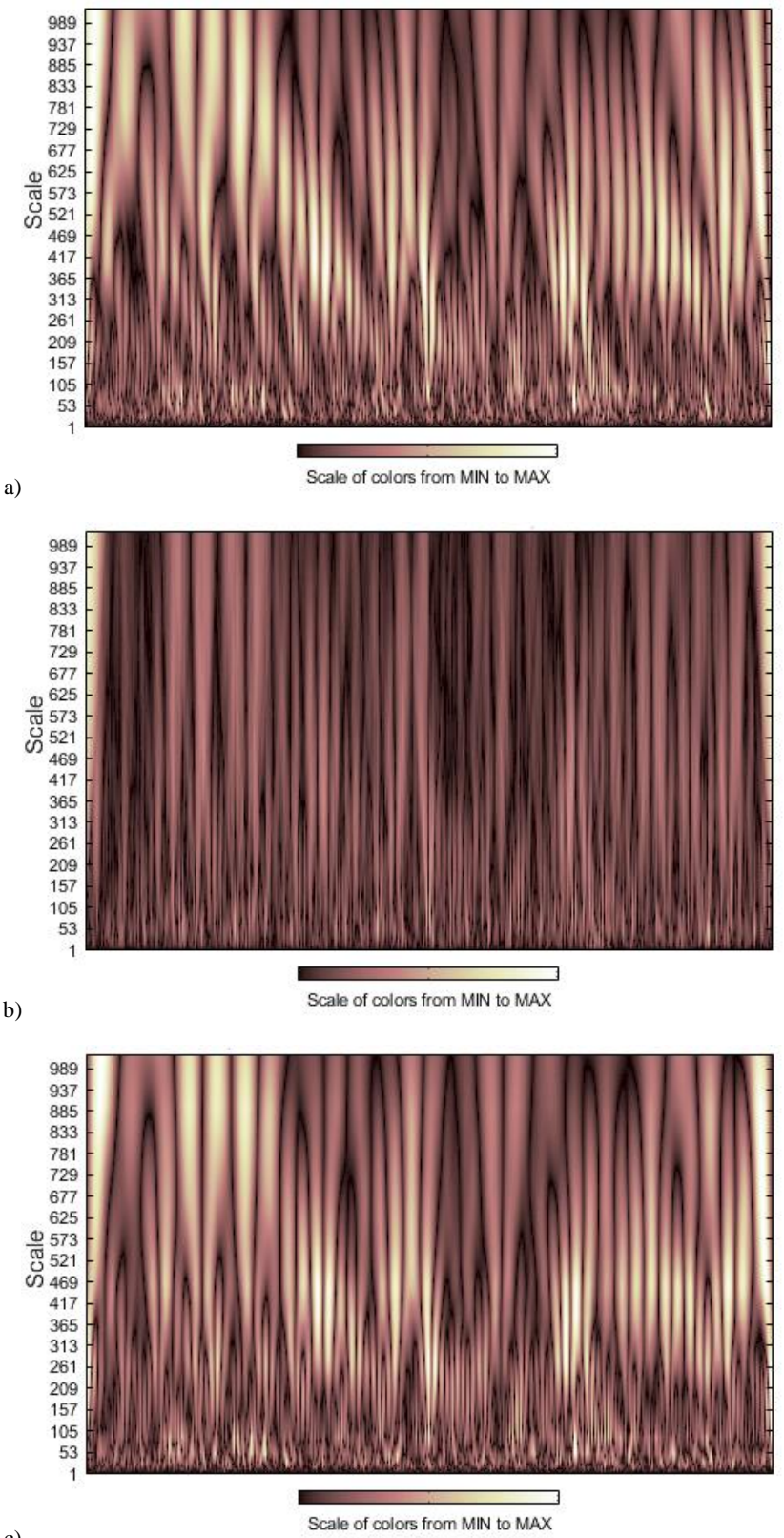

Fig. 4. Scalogram showing the result of analysis using a) Daubechies4 wavelet b) Haar wavelet, c) Symlet6 wavelet in continuous wavelet transform for $100 \%$ pulverized coal

The signals were acquired from 4 different flame zones at the sampling rate of 1000 samples per second. The total amount of data recorded for each zone reached over two million samples. Further studies were performed using the measurements of flame luminosity changes from the first flame and $16384\left(2^{\wedge} 14\right)$ samples (Fig. 1 and 3).16384 (2^14) samples (Fig. 1, 3).

At the first stage of research, the signals of changes in flame luminosity for both fuels were analyzed by means of continuous wavelet transform using the Haar, Daubechies4 and Symlet6 wavelets. Figures 3-4 show the analyzed signals in the form of scalograms, in which the scale corresponds to the frequency ranges. 
While analyzing the scalograms presented above, it can be stated that there are visible differences in the frequency structure of signals for particular types of fuel. The high-frequency components are better visible in the analysis conducted with Haar wavelet. In the case of the signals recorded during the combustion of pulverized coal, the following scale range were determined for which the amplitude increased: 400-900. In the case of the second fuel variant - mixture of pulverized coal and mazout, the range were as follows: 350-700. However, the greatest changes in amplitude became apparent when Symlet6 wavelet was used, due to a large number of vanishing moments.

The next stage of the analysis of changes in flame luminosity of pulverized coal and mixture of coal and mazout involved the application of discrete wavelet transform using Haar, Daubechies4 and Symlet6 wavelets decomposition eighth levels. Figures 5-6 present the scalograms of the analyzed signals.
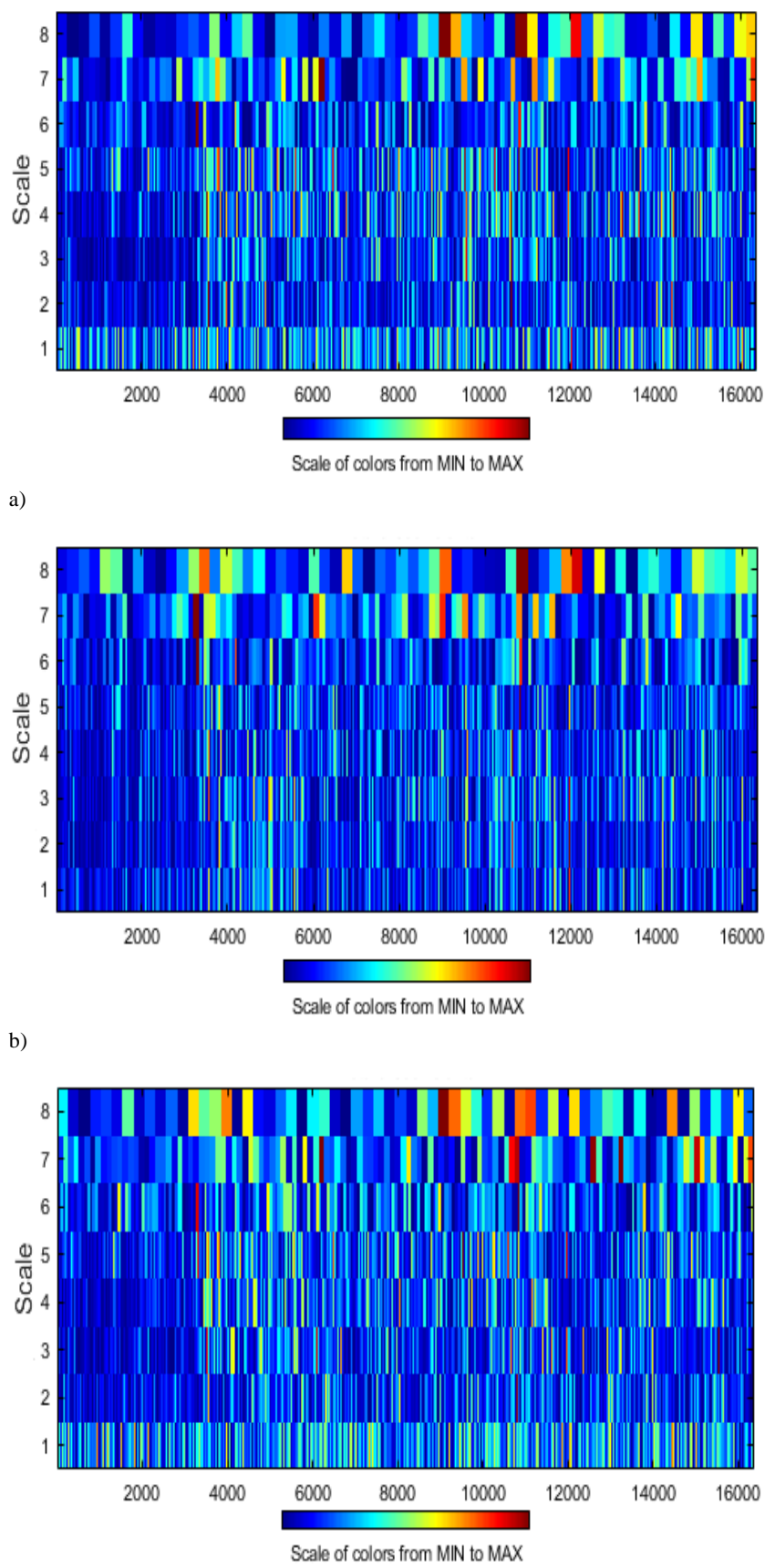

c)

Fig. 5. Scalogram showing the result of discrete wavelet transform analysis using a) Daubechies 4 wavelet, b) Haar wavelet, c) Symlet6 wavelet for mixture of coal and mazout
Similarly as in the case of continuous wavelet analysis, the interpretation of scalograms involves the assessment of scale ranges. On their basis, the greatest changes in amplitude within the signal presenting the changes in flame luminosity, can be observed using Haar wavelet. Since the signals from the combustion process are continuous, it was possible to employ both methods, i.e. continuous and discrete wavelet transform. While comparing both methods, the results of continuous analysis can be considered as easier to interpret, but also larger in terms of data size.
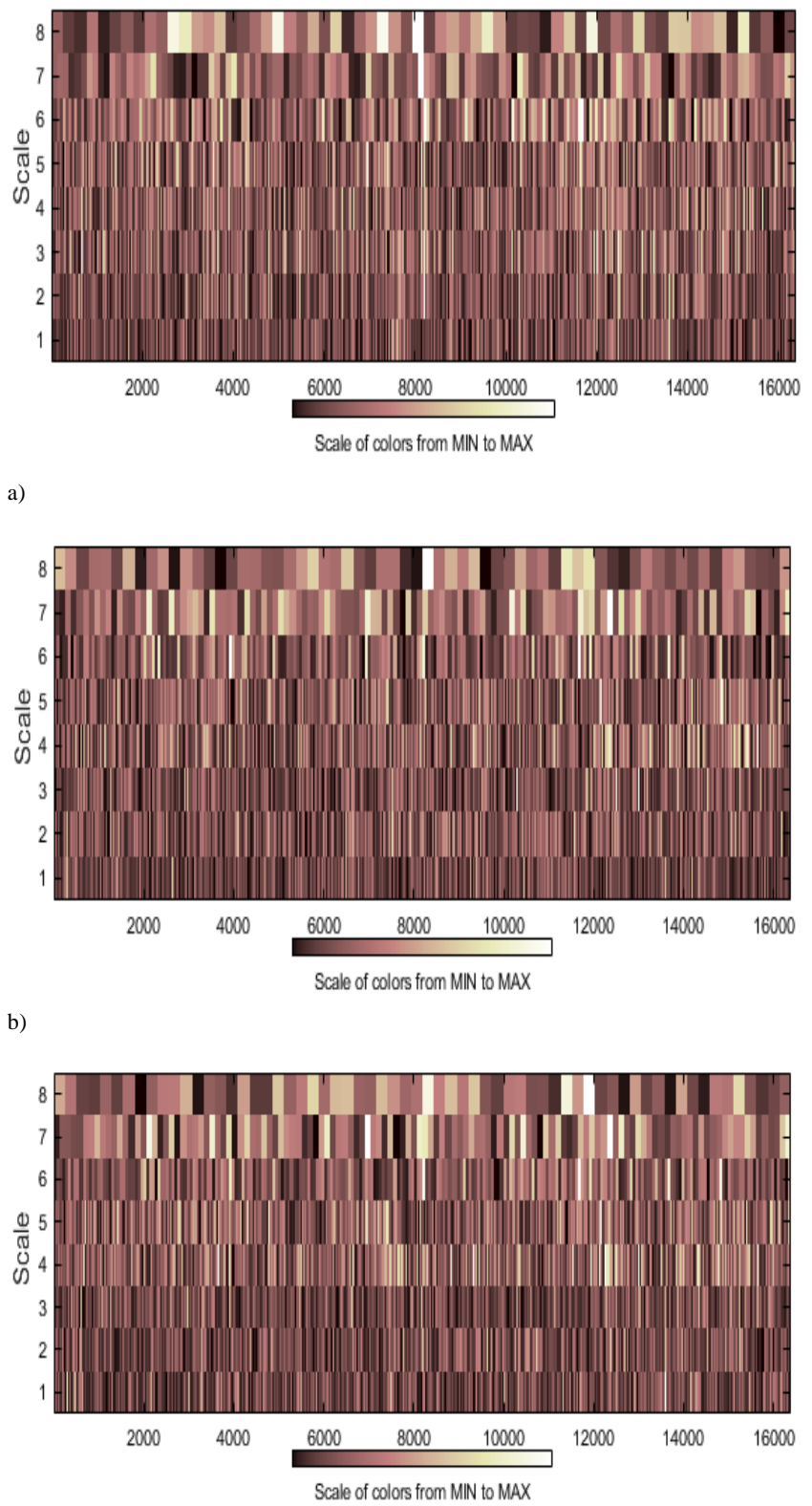

Fig. 6. Scalogram showing the result of discrete wavelet transform analysis using a) Daubechies 4 wavelet, b) Haar wavelet, c) Symlet6 wavelet for 100\% pulverized coal

\section{Conclusions}

Regardless of the type of combusted fuel, monitoring and diagnostics of the combustion process performed in the combustion chamber requires using specialized measuring systems. These solutions are intended to initially obtain and process selected data from the flame in real time and in a noninvasive way. Monitoring systems should be installed in each burner of the combustion chamber. Owing to this approach, 
the detailed assessment of the combustion process is possible. The measurement data, which were obtained from the flame, present the changes in flame luminosity or flame pulsation and they are recorded with high sampling rates. The analysis of these signals can be conducted with the use of multiple methods, including wavelet transforms.

The paper presented the selected signals of changes in flame luminosity for the process, in which the pulverized coal and mixture of coal and mazout were combusted. The measurement data were analyzed with the use of continuous and discrete wavelet transform. The results of transforms for both combustion options were presented with the use of scalograms for the Haar, Daubechies and Symlet wavelets. Using the scalograms allowed for observing the differences in the structure of the signal frequency. The greatest changes in the signal amplitude were observed after using the Symlet wavelet. For this type of wavelet, in the case of the signal of changes in flame luminosity for pulverized coal , the scale range of 400 - 900 was defined. For the signals recorded during the combustion of mazout, the scale range from 350 to 700 was specified. The interpretation of the scalograms in the case of discrete wavelet transform is also based on the evaluation of the scale ranges, as well as on the analysis of its features.

To sum up, it should be noted that the research presented in this paper focused on the designation of the scale values on the basis of which distinguishing between the types of combusted fuels was possible.

\section{References}

[1] Bi F., Li L., Zhang J., Ma T.: Source identification of gasoline engine noise based on continuous wavelet transform and EEMD-RobustICA. Applied Acoustics 100/2015, 34-42.

[2] Białasiewicz J. T.: Falki i aproksymacje.WNT, Warszawa 2000.

[3] Ibrahimoglu B., Yilmazoglu M. Z., Cucen A.: Numerical modeling of repowering of a thermal power plant boiler using plasma combustion systems. Energy, 103/2016, 38-48.

[4] Jiang Y. H., Li G. X., Li H. M., Li L., Zhang G. P.: Effect of flame inherent instabilities on the flame geometric structure characteristics based on wavele transform. International Journal of Hydrogen Energy 43(18)/2018, 9022-9035.

[5] Komada P., Ciesszczyk S., Zhirnova O., Askarova N.: Optyczna metoda diagnostyki gazu syntezowego z biomasy. Rocznik Ochrona Środowiska 18/2/2016, 271-283.
[6] Kordylewski W.: Spalanie I paliwa. Oficyna Wydawnicza Politechniki Wrocławskiej, Wrocław 2008

[7] Mallat S.: A Wavelet Tour of Signal Processing, Third Edition: The Sparse Way. Academic Press, 2008.

[8] Miller B.G., Clean coal engineering technology. Elsevier, 251-300, 2010.

[9] Siano D., Panza M. A., D'Agostino D.: Knock detection based on MAPO analysis, AR model and discrete wavelet transform applied to the in-cylinder pressure data: results and comparison. SAE International Journal of Engines $8(1) / 2015,1-13$

[10] Smolarz A., Kotyra A., Wójcik W., Ballester J.: Advanced diagnostics of industrial pulverized coal burner using optical methods and artificial intelligence. Experimental Thermal and Fluid Science 43/2012, 82-89.

[11] Wójcik W., Gromaszek K., Kotyra A., Lawicki T.: Pulverized coal combustion boiler efficient control. Przegląd Elektrotechniczny 88/11b/2012, 316-319.

[12] Wójcik W., Gromaszek K., Shegebayeva Z., Suleimenov B., Burlibay A. Optimal control for combustion process. Przegląd Elektrotechniczny 90/4/2014, $157-160$.

[13] Wójcik W., Gromaszek K., Smailova S.: Using optical signals for pulverised coal combustion process optimal control to increase economic efficiency of the boiler. Actual Problems of Economics 142/2013, 307-311.

[14] Wójcik W.: Fiber-optic system for monitoring the combustion process. PAK 53/2007, 24-28

[15] Wójcik W.: Nowoczesne technologie paliw i spalania. Monografie Komitetu Inżynierii Środowiska PAN, Lublin 2011

[16] Wu J. D., Chen J. C.: Continuous wavelet transform technique for fault signal diagnosis of internal combustion engines. NDT \& e International 39(4)/2006, 304-311.

[17] Yan C., Zhang T., Sun Y., Tang H., Li H.: A hybrid variable selection method based on wavelet transform and mean impact value for calorific value determination of coal using laser-induced breakdown spectroscopy and kernel extreme learning machine. Spectrochimica Acta Part B: Atomic Spectroscopy $154 / 2019,75-81$.

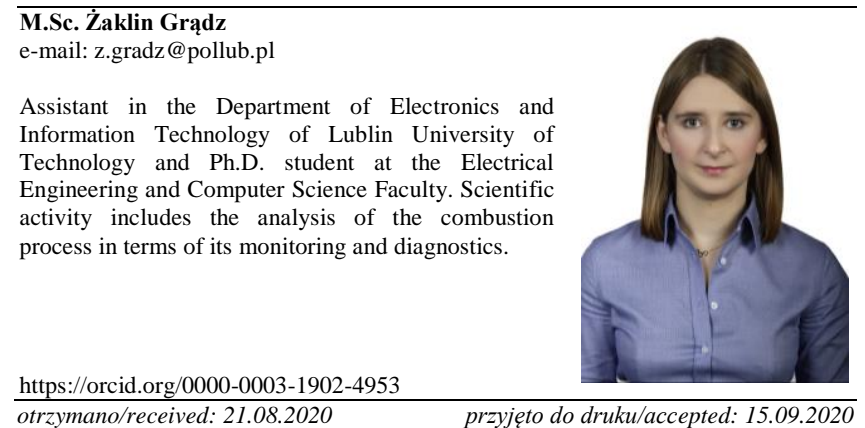

